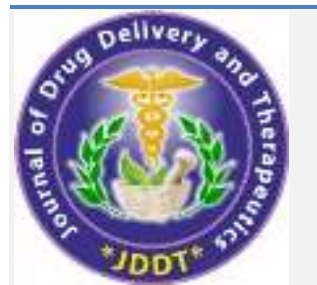

\section{Journal of Drug Delivery and Therapeutics}

Open Access to Pharmaceutical and Medical Research

Copyright (C) 2022 The Author(s): This is an open-access article distributed under the terms of the CC BY-NC 4.0 which permits unrestricted use, distribution, and reproduction in any medium for non-commercial use provided the original author and source are credited

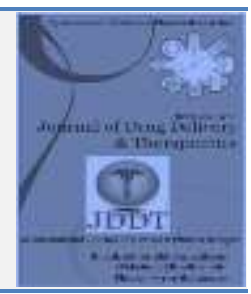

Review Article Access Full Text Article

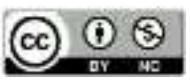

\title{
A Review of Plants with Remarkable Hepatoprotective Activity
}

\author{
Sanjana Meshack ${ }^{*}$ (1i), Suchita Gupta ${ }^{2}$ (ii) \\ ${ }^{1}$ Final Year Student, MSc Clinical Research, Institute of Clinical Research, India (ICRI), Ajeenkya DY Patil University, Pune, India \\ ${ }^{2}$ Assistant Professor, Institute of Clinical Research, India (ICRI), Ajeenkya DY Patil University, Pune, India
}

\section{Article Info:}

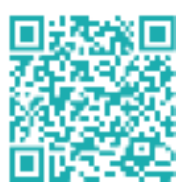

Article History:

Received 10 November 2021 Reviewed 13 December 2021 Accepted 18 December 2021 Published 15 January 2022

\section{Cite this article as:}

Meshack S, Gupta S, A Review of Plants with Remarkable Hepatoprotective Activity, Journal of Drug Delivery and Therapeutics. 2022; 12(1):194202

DOI: http://dx.doi.org/10.22270/jddt.v12i1.5283

\section{Abstract}

Liver being vulnerable to exogenous substances makes disease associated with it a matter of worldwide concern. Several research thus focus on hepatoprotection .Preventive and therapeutic activity of plants as a hepatoprotective agent is a topic of interest for researchers. Hepatotoxic agents like carbon tetrachloride, paracetamol, isoniazide etc. increase the serum biomarkers of liver where ALT is more specific than AST in detecting liver injury. Drug-induced liver injury (DILI) wherein more than 900 drugs have been implicated in causing liver injury. Plant phenolics include simple phenols, phenolic acids, coumarins, lignans, flavo noids, diarylalkanoids, stilbenoids, proanthocyanins, tannins, and anthocyanins some alkaloids. The greater the content of alkaloids, flavonoids, and saponins in an extract, the higher the hepatoprotective activity possessed by the extract. This paper reviews some plants documented between the periods of 2011-2021 with remarkable heptoprotective activity and discusses the various hepatotoxic agents used, its mechanism and hepatoprotective agents present in the specific plant.

Keywords: Hepatoprotective plants, flavonoids, saponin, alkaloids, hepatotoxicity, drug induced liver injury, hepatotoxic agents

\footnotetext{
*Address for Correspondence:

Sanjana Meshack, Final year student, MSc clinical research, Institute of Clinical Research, India (ICRI), Ajeenkya DY Patil University, Pune, India Orchid ID: https://orcid.org/0000-0002-4054-2328
}

\section{INTRODUCTION}

Liver which is the largest gland in the body is a multifunctioning organ, responsible for metabolism, detoxification, secretion, synthesis, storage and immunological functions. The liver is permanent susceptible to exogenous substances e.g. drugs, alcohol and environmental toxins, which can lead to liver disorders, such as hepatocellular, cholestatic (obstructive) and mixed type of the liver disorders ${ }^{1}$.Liver diseases have become a global concern worldwide and deaths caused by liver diseases are rising each year at an alarming rate ${ }^{2}$. It is steadily increasing over the years and World Health Organisation (WHO) has projected in its World Health Statistics of 2020 to be the eleventh most important cause of death in the world by 2030 and may be the tenth most common cause of death in India by 2020 .Plants have been used since ancient times in the treatment of liver diseases, several research has proven the preventive and therapeutic activity of plants as a hepatoprotective agent. People are becoming aware about the various benefits and preferring the alternative medicine, for their health. As in 2018, 170 WHO Member States have acknowledged their use of Traditional and complementary medicine. Ayurveda a time honoured Indian system of medical practice has multitude proven formulations for the treatment of liver diseases. The plants which protect the liver contain variety of active constituents like flavonoids, glycosides, monoterpenes, coumarins, lignans, essential oil, carotenoids, organic acids, alkaloids and xanthene ${ }^{3}$.Here this paper reviews some incredible plants for their hepatoprotective activity taken from various documented literature from the period of 2011-2021.

\section{Table 1: Plant Description}

\begin{tabular}{|l|l|l|l|}
\hline Name of the plant & Common name & Part of plant used & Type of extract \\
\hline $\begin{array}{l}\text { Cichorium Intybus and Cynara } \\
\text { Scolymus }\end{array}$ & Chicory / Kasani / Artichoke Ahtichoke & $\begin{array}{l}\text { Cichorium intybus root and } \\
\text { Cynara Scolymus leaves }\end{array}$ & Ethanolic extract \\
\hline Foeniculum Vulgare $^{1}$ & Fennel /sauf & Seed & Ethanolic extract \\
\hline Cordia Sebestena L. $^{5}$ & Geiger / Lal Lasoda & Fruit & Ethanolic extract \\
\hline
\end{tabular}




\begin{tabular}{|c|c|c|c|}
\hline Curcuma Heyneana $^{6}$ & Temu Giring a variety of Turmeric & Rhizome & Ethanolic extract \\
\hline 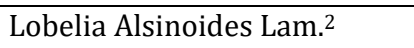 & Chickweed/Bhujbhuja kharpatwar & Whole plant & Kalka Preparation \\
\hline $\begin{array}{l}\text { Three Varieties of the Passion } \\
\text { Fruit (Passiflora Sp.) }\end{array}$ & Passion Fruit & $\begin{array}{l}\text { Peel of the fruit (red, yellow } \\
\text { and purple) }\end{array}$ & Ethanolic extract \\
\hline Phyllanthus fraternus ${ }^{8}$ & Gulf leaf flower / Bhumiamlaki & Leaves & Aqueous Extract \\
\hline Pavetta Indica LINN ${ }^{9}$ & Indian Pellet shrub / Kankara & Leaves & Ethanolic Extract \\
\hline Mimosa Pudica10 & Shameplant/Chuimuhi & Leaves & Ethanolic Extract \\
\hline Terminalia Coriacea $^{3}$ & Belong to Arjun Family & Leaves & Methanolic Extract \\
\hline Bambusa Bambos $^{11}$ & Bamboo / Bans & Shoot extract & Methanolic Extract \\
\hline Rosa Canina 12 & Dog Rose & Fruit & Ethanolic Extract \\
\hline Garcinia Pedunculata 13 & Bor Thekera /tikul & Fruit & Aqueous Extract \\
\hline Tetrapleura Tetraptera ${ }^{14}$ & Aridan/Prekese & Fruit & Methanolic Extract \\
\hline Feijoa Sellowiana ${ }^{15}$ & Horn of plenty/pineapple guava' & Fruit & Ethanolic Extract \\
\hline Piper Cubeba 16 & Tailed pepper, Java pepper. & Fruit & Ethanolic Extract \\
\hline Feronia Limonia 17 & wood apple/elephant apple/ kowit & Fruit pulp & Ethanolic Extract \\
\hline Solanum Xanthocarpum ${ }^{18}$ & $\begin{array}{l}\text { yellow-fruit nightshade, Thai green } \\
\text { eggplant,kantakari }\end{array}$ & Fruit & Ethanolic Extract \\
\hline
\end{tabular}

\section{HEPATOTOXICITY}

Injury or damage to the liver caused by substances like drugs, herbal agents, industrial chemical agents or nutritional supplements. Liver being the vital site for metabolism and biotransformation it becomes highly susceptible to damage. More than 900 drugs have been implicated in causing liver injury and it is the most common reason for a drug to be withdrawn from the market ${ }^{19}$.Druginduced liver injury (DILI) represents a diverse set of responses that occur after exposure to any manufactured or naturally occurring chemical compound ${ }^{20}$.The DILIrank dataset consists of 1,036 FDA-approved drugs that are divided into four classes where 192 Most DILI concern-, 278 Less DILI concern, 312 No DILI concern where there is confirmed causal relationship between a drug and liver injury and the last group 254 Ambiguous-DILI-concern where the causality remains undetermined. LiverTox is another dataset providing up-to-date, information on the diagnosis, cause, frequency, clinical patterns and management of liver injury attributable to prescription and non-prescription medications and selected herbal and dietary supplements.

\section{Table 2: Types of DILI}

\begin{tabular}{|l|l|}
\hline Intrinsic DILI & Idiosyncratic DILI \\
\hline $\begin{array}{l}\text { It affects every individual } \\
\text { at the same dose }\end{array}$ & $\begin{array}{l}\text { It affects individuals with risk factors (risk of unpredictable interactions among genetic, non- } \\
\text { genetic factors like age, sex, existing imumunocompromised diseases, daily dose, and } \\
\text { metabolism factors.) }\end{array}$ \\
\hline Predictable & Unpredictable \\
\hline Dose dependent & Non-Dose-Dependent \\
\hline E.g. Acetaminophen etc. & E.g. tyrosine kinase inhibitors,antitubercular drugs etc. \\
\hline
\end{tabular}

Table 3: Bio Chemical Classification of DILI'20,21

\begin{tabular}{|l|l|l|}
\hline Hepatocellular & Cholestatic & Mixed Hepatocellular/Cholestatic Pattern \\
\hline $\begin{array}{l}\text { ALT } 2 \text { to } 5 \text { times }>\text { the upper limit of } \\
\text { normal (ULN) and/or an ALT/ALP } \\
\text { ratio }>\text { than 5 }\end{array}$ & $\begin{array}{l}\text { ALP 3 times }>\text { ULN and/or an ALT/ALP } \\
\text { ratio }<2\end{array}$ & $\begin{array}{l}\text { ALT 2 to 5 times >the ULN and ALP 3 } \\
\text { times }>\text { the ULN and/or an ALT/ALP ratio } \\
\text { between 2 and 5. }\end{array}$ \\
\hline hepatocyte necrosis, poor prognosis & $\begin{array}{l}\text { bland cholestasis is the result of } \\
\text { abnormal biliary secretion, with no } \\
\text { hepatocellular damage }\end{array}$ & $\begin{array}{l}\text { cholestasis with concomitant hepatic } \\
\text { parenchymal damage }\end{array}$ \\
\hline
\end{tabular}

Hepatotoxic agents increase the serum levels of ALT( alanine transaminase),AST(aspartate aminotransferase), ALP (Alkaline phosphatase) TB(total bilirubin), DB(direct bilirubin) and TG (Serum Triglycerides),cholestrol,urea and decrease the serum levels of Albumin, GSH glutathione reductase and TP(total protein). ALT is more specific than AST in detecting liver damage as AST can be found not only in the liver but also in the heart, muscle, kidney as well as brain. ${ }^{6}$ 
Table 4: Description of Hepatotoxic Agent

\begin{tabular}{|c|c|c|}
\hline Name of the plant & Hepatotoxicity inducing agent & Biochemical/Histopathological tests \\
\hline $\begin{array}{l}\text { Cichorium Intybus } \\
\text { and Cynara } \\
\text { Scolymus }\end{array}$ & $\begin{array}{l}\text { Paracetamol at } 0.5 \mathrm{mg} / \mathrm{kg} \\
\text { bodyweight }\end{array}$ & $\begin{array}{l}\text { Creatinine phosphokinase (CPK), Alanine Aminotransferase } \\
\text { (SGPT or ALT), Aspartate Aminotransferase (SGOT or AST), } \\
\text { Lactate Dehydrogenase (LDH), creatinine, Gamma-Glutamyl } \\
\text { Transferase (GGT), Uric acid and weight }\end{array}$ \\
\hline $\begin{array}{l}\text { Foeniculum } \\
\text { Vulgare }^{1}\end{array}$ & Paracetamol at $2 \mathrm{~g} / \mathrm{kg}$ body weight & $\begin{array}{l}\text { Aspartate amino transferase (AST), alanine amino transferase } \\
\text { (ALT), Alkaline phosphatase (ALP), bilirubin. }\end{array}$ \\
\hline $\begin{array}{l}\text { Cordia Sebestena } \\
\text { L. } 5\end{array}$ & Simvastatin at $20 \mathrm{mg} / \mathrm{kg}$ body weight & $\begin{array}{l}\text { SGOT(Serum glutamic oxaloacetic transaminase), SGPT (serum } \\
\text { glutamic pyruvic transaminase), cholesterol, bilirubin, urea, } \\
\text { albumin, total protein and red blood cells (RBC), white blood } \\
\text { cells (WBC) haemoglobin (Hb), platelets and lymphocytes and } \\
\text { liver histopathology study }\end{array}$ \\
\hline $\begin{array}{l}\text { Curcuma } \\
\text { Heyneana }^{6}\end{array}$ & $\begin{array}{l}\text { Isoniazid at the dose of } 50 \mathrm{mg} / \mathrm{kg} \text { and } \\
\text { rifampin at dose of } 100 \mathrm{mg} / \mathrm{kg} \text { body } \\
\text { weight }\end{array}$ & $\begin{array}{l}\text { Alanine transaminase (ALT) and aspartate transaminase (AST), } \\
\text { livers were collected for histopathology study }\end{array}$ \\
\hline $\begin{array}{l}\text { Lobelia Alsinoides } \\
\text { Lam. }{ }^{2}\end{array}$ & $\begin{array}{l}\text { Carbon Tetrachloride } 1: 1 \text { mixture in } \\
\text { olive oil at } 1.25 \mathrm{ml} / \mathrm{kg} \text { bodyweight }\end{array}$ & $\begin{array}{l}\text { AST), ALT, ALP, total bilirubin, total protein, albumin and total } \\
\text { cholesterol, liver for histopathology study. }\end{array}$ \\
\hline $\begin{array}{l}\text { Three Varieties of } \\
\text { the Passion Fruit } \\
\text { (Passiflora Sp.) }^{7}\end{array}$ & $\begin{array}{l}\text { Paracetamol at } 500 \mathrm{mg} / \mathrm{kg} \text { body } \\
\text { weight }\end{array}$ & ALT, AST, Urea and Creatinine \\
\hline $\begin{array}{l}\text { Phyllanthus } \\
\text { Fraternus }^{8}\end{array}$ & $\begin{array}{l}\text { Carbon Tetrachloride : Olive oil (dose } \\
\text { not mentioned) }\end{array}$ & $\begin{array}{l}\text { SGOT, SGPT, ALP, bilirubin, cholesterol, and total protein, liver } \\
\text { tissues for histopathology study }\end{array}$ \\
\hline $\begin{array}{l}\text { Pavetta Indica } \\
\text { LINN }^{9}\end{array}$ & $\begin{array}{l}\text { Paracetamol at } 2000 \mathrm{mg} / \mathrm{kg} \\
\text { bodyweight }\end{array}$ & $\begin{array}{l}\text { SGOT, SGPT, Albumin, Globulin, Total bilirubin, direct bilirubin, } \\
\text { total protein }\end{array}$ \\
\hline Mimosa Pudica10 & $\begin{array}{l}\text { High fat diet (HFD) for } 2 \text { weeks and } \\
\text { streptozotocin (STZ) }(35 \mathrm{mg} / \mathrm{kg} \text { body } \\
\text { weight).-induced type } 2 \text { diabetic rats }\end{array}$ & Glucose, insulin, AST, ALT, ALP and LDH \\
\hline $\begin{array}{l}\text { Terminalia } \\
\text { Coriacea }^{3}\end{array}$ & $\begin{array}{l}\text { Carbon Tetrachloride at } 2 \mathrm{ml} / \mathrm{kg} \\
\text { bodyweight }\end{array}$ & $\begin{array}{l}\text { AST, ALT, ALP ,direct bilirubin, total bilirubin and Cholesterol, } \\
\text { liver for histopathology study }\end{array}$ \\
\hline $\begin{array}{l}\text { Bambusa } \\
\text { Bambos }^{11}\end{array}$ & $\begin{array}{l}\text { Carbon Tetrachloride at } 1 \mathrm{~mL} / \mathrm{kg} \\
\text { body weight }\end{array}$ & $\begin{array}{l}\text { Aspartate Amino Transaminase (AST), Alanine Amino } \\
\text { Transaminase (ALT), Alkaline Phosphatase (ALP) and Total } \\
\text { Bilirubin }\end{array}$ \\
\hline Rosa Canina ${ }^{12}$ & $\begin{array}{l}\text { Carbon tetrachloride } 1 \mathrm{ml} / \mathrm{kg} \text { body } \\
\text { weight }\end{array}$ & $\begin{array}{l}\text { aspartate aminotransferase (AST), alanine amino transaminase } \\
\text { (ALT), alkaline phosphatase (ALP), albumin (ALB), total protein } \\
\text { (TP) and malondialdehyde (MDA), histopathological study }\end{array}$ \\
\hline $\begin{array}{l}\text { Garcinia } \\
\text { Pedunculata } 13\end{array}$ & Paracetamol at $1 \mathrm{~g} / \mathrm{kg}$ body weight & $\begin{array}{l}\text { acute oral toxicity test,ALT,AST,alkaline phosphatase, } \\
\text { histopathological study }\end{array}$ \\
\hline $\begin{array}{l}\text { Tetrapleura } \\
\text { Tetraptera }\end{array}$ & $\begin{array}{l}\text { Carbon tetrachloride at } 0.75 \mathrm{mg} / \mathrm{kg} \\
\text { body weight }\end{array}$ & $\begin{array}{l}\text { ALT, AST, alkaline phosphatase, bilirubin, histopathological } \\
\text { study, Measurement of Lipid Peroxide }\end{array}$ \\
\hline Feijoa Sellowiana $^{15}$ & $\begin{array}{l}\text { methylenedioxymethamphetamine( } \\
\text { MDMA) at } 10 \mathrm{~mL} / \mathrm{Kg} \text { body weight }\end{array}$ & ALT, AST, glutathione reductase, histopathology study \\
\hline Piper Cubeba ${ }^{16}$ & $\begin{array}{l}\text { Carbon tetrachloride at } 1 \mathrm{ml} / \mathrm{kg} \text { body } \\
\text { weight }\end{array}$ & $\begin{array}{l}\text { antioxidant potential tested by (DPPH) free radical scavenging } \\
\text { activity, hydroxyl radical scavenging activity, nitric oxide radical } \\
\text { scavenging activity and hydrogen peroxide radical scavenging } \\
\text { activity, } \\
\text { ALT, AST, ALP, TB, DB ,TG and Total proteins along with } \\
\text { histopathology study } \\
\text { Lipid Peroxidation (LPO), Reduced Glutathione (GSH) and } \\
\text { Catalase Level (CAT) determination. }\end{array}$ \\
\hline Feronia Limonia ${ }^{17}$ & $\begin{array}{l}\text { Paracetamol at } 500 \mathrm{mg} / \mathrm{kg} \text { body } \\
\text { weight }\end{array}$ & $\begin{array}{l}\text { AST, ALT, ALP, Total Bilirubin, Total cholesterol, Triglycerides \& } \\
\text { the body weight. }\end{array}$ \\
\hline $\begin{array}{l}\text { Solanum } \\
\text { Xanthocarpum } 18\end{array}$ & $\begin{array}{l}\text { Carbon tetrachloride at } 1 \mathrm{ml} / \mathrm{kg} \text { body } \\
\text { weight }\end{array}$ & $\begin{array}{l}\text { Aspartate aminotransferase (AST), alanine aminotransferase } \\
\text { (ALT), Serum alkaline phosphatise (SALP) and total bilirubin, } \\
\text { antioxidant activities as lipid peroxidation (LPO), reduced } \\
\text { glutathione (GSH), superoxide dismutase (SOD) and catalase } \\
\text { (CAT) were screened along with histopathological studies. }\end{array}$ \\
\hline
\end{tabular}


1. Carbon tetrachloride- Out of 18 research papers reviewed 8 used Carbon tetrachloride $\left(\mathrm{CCl}_{4}\right)$ as the hepatotoxin in (1:1) ratio mixed in olive oil /liquid paraffin. The carbon tetrachloride administration causes oxidative damage.ROS causes membrane lipid peroxidation, cell and mitochondrial membrane degradation, endoplasmic reticulum dysfunction, and intracellular macromolecule damage ${ }^{35}$, fibrosis, inflammation and fatty degeneration in the liver.

2. Paracetamol- Paracetamol also known as acetaminophen is the most common cause of DILI. It is the next frequent hepatotoxin used in the reviewed papers for inducing hepatotoxicity. Mitochondrial dysfunction is attributed as the main source of free radicals and oxidative stress in paracetamol hepatotoxicity .Increased activity of mitochondrial complex I, a site for free radical generation seen in paracetamol overdose is directly related degree of liver injury ${ }^{22}$.

3. Methylenedioxymethamphetamine (MDMA) - MDMA or ecstasy is an amphetamine derivative which has been abused as a widespread recreational. Liver is a target organ for MDMA toxicity. MDMA is metabolized by cytochromes $\mathrm{P}_{450} 2 \mathrm{D}, 2 \mathrm{~B}$ and 3 Aand reactive metabolites are readily oxidized to the corresponding o-qiuinones and reactive oxygen species (ROS) which results in hepatotoxicity ${ }^{15}$.

4. Simvastatin- Statins can lead to idiosyncratic liver injury; More than 50 cases of liver injury have been reported in association with atorvastatin and simvastatin. Mortality from liver injury has only been associated with atorvastatin and simvastatin $^{23}$. Mitochondrial dysfunction is one of the major factors that explain the mechanism of statin-induced hepatotoxicity. Another major reason for statin induced hepatotoxicity is that mitochondria or cytochromeP450dependent metabolism act as Reactive Oxygen Species (ROS) generation systems and participate in cell death processes ${ }^{24}$.

5. Isoniazid and rifampin- DILI may occur to the tuberculosis patients who consume INH for 6 to 9 months, RIF for 4 months, or a combination of INH and RIF for 4 months. INH along with RIF produces toxic metabolites or oxidants such as acetylhydrazine $(\mathrm{AcHz})$ and hydrazine $(\mathrm{Hz})$ which are oxidized by microsomal enzymes P450 especially CYP2E1 into radical metabolites. These metabolites cause hepatotoxicity ${ }^{6}$.

6. High fat diet (HFD) and streptozotocin (STZ) - High fat diet (HFD) and streptozotocin (STZ) induced type 2 diabetes mellitus. Liver is an important organ for glucose homeostasis. In diabetes mellitus the liver damage is related to free radicals formation through glucose oxidation, decrease in antioxidant defence mechanism pathway, onenzymatic glycation of protein and cytokine production. Chronic hyperglycaemia is a major reason for oxidative stress which leads to pathological changes in liver cell.

\section{HEPATOPROTECTIVE ACTIVITY}

Compounds which restore liver damage or act as boon for the liver are hepatoprotective agents. In the normal state, antioxidant defence systems such as SOD, catalase, and glutathione peroxidase enzymes eliminate the damaging free radicals 35 . There are several plants reported to have phytoconstituents which proves the hepatoprotective activity.

\section{Table 5: Description of Hepatoprotective Agent}

\begin{tabular}{|c|c|}
\hline Name of the plant & Hepatoprotective agent \\
\hline $\begin{array}{l}\text { Cichorium Intybus } \\
\text { Cynara Scolymus }\end{array}$ & $\begin{array}{l}\text { Esculetin, Hydroxycinnamic acid, Caffeoylquinic acid, Dicaffeoylquinic acid, Chicoricacid }{ }^{25} \text {, } \\
\text { cichotyboside }^{26} \text {, flavonoids, saponins }{ }^{4} \\
\text { Flavones, flavanones, flavonols, coumarins, and phenolic acids }{ }^{4}\end{array}$ \\
\hline Foeniculum vulgare & d-limonene ${ }^{1}$ \\
\hline Cordia sebestena L. & Flavonoids 5 \\
\hline Curcuma heyneana & $\begin{array}{l}\text { Flavonoids, saponins, tannins,glycosides,steroids/triterpenoids, curcuminoid which } \\
\text { comprises of comprises curcumin, demethoxycurcumin and bisdemethoxycurcumin } 6\end{array}$ \\
\hline Lobelia Alsinoides Lam. & Steroids, alkaloids, phenol and tannins ${ }^{2}$ \\
\hline $\begin{array}{l}\text { Three Varieties of the Passion } \\
\text { Fruit (Passiflora Sp.) }\end{array}$ & Alkaloids, flavonoids, steroids, triterpenoids, saponins, tannins, glycosides, and phenolic ${ }^{7}$ \\
\hline Phyllanthus Fraternus & Phenolic and flavonoid content ${ }^{27}$ \\
\hline Pavetta Indica LINN & $\begin{array}{l}\text { Flavonoids and their glycosides, alkaloids, sterols, phenolics, lignins, terpenoids, } \\
\text { coumarins,saponins,phenols } 28\end{array}$ \\
\hline Mimosa Pudica & Flavonoids, glycosides, terpinoids, alkaloids, phenol and tannin ${ }^{10}$ \\
\hline Terminalia coriacea & $\begin{array}{l}\beta \text { - Sitosterol, Stigmasterol, 1H-Inden-1-one,2,3-dihydro-3,3,5,6,-tetramethyl, n- } \\
\text { hexadecanoic acid, flavonoids and tannins }{ }^{3}\end{array}$ \\
\hline Bambusa Bambos & Flavonoids, steroidal alkaloids, etc ${ }^{11}$ \\
\hline Rosa Canina & Flavonoids, phenolic acids, tannins, carotenoids ${ }^{12}$ \\
\hline Garcinia Pedunculata & Flavonoids, saponins, glycosides, steroids, alkaloids and phenols ${ }^{13}$ \\
\hline Tetrapleura tetraptera & Flavonoid,polyphenols,flavanol ${ }^{29}$ \\
\hline Feijoa sellowiana & polyphenols $^{15}$ \\
\hline
\end{tabular}




\begin{tabular}{|l|l|}
\hline Piper cubeba & Essential oil, terpenoids, and flavonoids ${ }^{30}$ \\
\hline Feronia limonia & Flavonoids $^{17}$ \\
\hline Solanum xanthocarpum & Flavonoids, steroidal alkaloids ,triterpenes, quercitrin, apigenin glycosides ${ }^{18}$ \\
\hline
\end{tabular}

Plant phenolics include simple phenols, phenolic acids, coumarins, lignans, flavonoids, diaryl-alkanoids, stilbenoids, proanthocyanins, tannins, and anthocyanins some alkaloids. They protect against oxidative damage by donating hydrogen or electron to free radicals and aid in stabilizing cell membrane networks and inhibiting the formation and expression of inflammatory cytokines like tumor necrosis factor alpha (TNF- $\alpha$ ), Transforming Growth Factor beta (TGF- $\beta$ ) and varieties of interleukins (IL-6, IL-2, IL-8) ${ }^{31}$.

Flavonoids -Enhance the antioxidant functions of liver by increasing the level of superoxide dismutase, glutathione stransferase and glutathione peroxidase, improve insulin sensitivity and inhibit hepatic stellate cell activation by regulating the activities of the enzymes such as heme oxygenase-1, cytochrome $\mathrm{P} 450$ and telomerase. Reduce inflammatory reaction by restraining the expression of tumor necrosis factor- $\alpha$, interferon- $\gamma$ and interleukin- 6 , and mediate apoptosis and autophagy by controlling the pathways of genes-p 53-genetics, nuclear factor $\kappa B$ and phosphatidylinositol 3-kinase/protein kinase B signaling, which provides an alternative way for the treatment of liver injury ${ }^{32}$. Three flavonoids, rutin, robinin and gossypetin 3glucuronide 8-glucoside were isolated and characterized from TCLME(methanolic extract of T. coriacea leaves for the first time ${ }^{33}$.

The administration of Piper cubeba ethanolic extract PCEE significantly scavenge reactive free radicals that diminish oxidative stress or damage of liver tissue and provoke the activities of the hepatic antioxidant enzymes. Downregulated the $\mathrm{CCl}_{4}$-induced proinflammatory cytokines TNF $\alpha$ and IL- 6 mRNA expression ,while it upregulated the IL10 and induced hepatoprotective effect by down-regulating mRNA expression of iNOS and $\mathrm{HO}-1$ gene ${ }^{30}$.A study conducted to assess Hepatoprotective effects and structureactivity relationship of five flavonoids against lipopolysaccharide/D-galactosamine induced acute liver failure in mice showed flavonoids activity on anti-oxidation, anti-inflammation, and anti-apoptosis. After lipopolysaccharide (LPS)/D-galactosamine (D-GalN) administration, five flavonoids inhibited oxidative activities with reducing nitric oxide synthase (iNOS), malondialdehyde (MDA), and improving catalase (CAT), superoxide dismutase (SOD), total antioxidant capacity (T-AOC), nuclear factor erythroidderived 2-related factor 2 (Nrf2) and heme oxygenase-1 (HO1). They reduced pro-inflammatory cytokines, prevented the phosphorylation of IKK, I $\kappa \alpha \alpha$, and NF- $\mathrm{B} / \mathrm{p} 65$ in the NF $\kappa \mathrm{B}$ signaling pathway. Also inhibited hepatocyte apoptosis through increasing Bcl-2/Bax ratio and suppressing the Caspase family proteins ${ }^{34}$.

Esculetin-reduce the expression of inflammatory cytokines such as TNF- $\alpha$, IL-1 $\beta$, and IL-6. Increased the amount of Nrf2 (which plays a role in resistance to oxidative stress) phosphorylation and simultaneously decrease the amount of its inhibitor Keap1.Esculetin induces antioxidant effects by inducing antioxidant enzymes, which is marked by a significant increase in SOD. Esculetin decreased neutrophil filtration 35 .

Hydroxycinnamic acids (HCs) are phenolic compounds , subclass includes coumaric acid,ferulic acid, caffeic acid,cinnamic acid, chlorogenic acid. Caffeic acid can modulate the expression of kelch-like ECH associated protein-1 (Keap1), a hepatic carcinoma factor, by interacting with Nrf2 binding site and restraining it from binding to Keap 1 and elevating the expressions of vital antioxidative signals like $\mathrm{HO}-1^{31}$.

Chichoric acid-Activates nuclear factor-erythroid 2-related factor 2 (Nrf2) pathway with increasing the level of AMPactivated protein kinase (AMPK). Treatment led to improved protein levels of autophagy genes. The hepatoprotective impact of chicory was due to aversion of lipid peroxidation, supporting of endogenous antioxidant, and overexpression of genes encoding antioxidant enzymes, thus averting DNA damage ${ }^{25}$. Phenolic structures in the Cynara scolymus extract have a pivotal role in free radical mediated processes inhibition ${ }^{4}$.Several studies prove the hepatoprotective activity of C.scolymus but failed in the reviewed comparison study, a concentration higher is believed to show hepatoprotection.

Curcumin-It exerts its protective and therapeutic effects in oxidative coupled

liver diseases by suppressing proinflammatory cytokines, lipid peroxidation products, hepatic stellate cells, and Akt activation. Curcumin improve oxidative stress induced expression of

Nrf2, SOD, CAT, and GSH. Curcumin acts as a free-radical scavenger over the activity of different kinds of ROS with its active phenolic pharmacophore, b-diketone and methoxy group ${ }^{31}$. Functional hydroxyl groups in flavonoids mediate their antioxidant effects by scavenging free radicals, also activate glutathione peroxidase system as protective enzyme and inhibit the enzymes which are involved in reactive oxygen species generation.curcumin stimulates antioxidant enzyme activity like glutathione peroxidase, superoxide dismutase and catalase. Curcumin is capable of scavenging oxygen free radicals such as superoxide anions and hydroxyl radicals which are important in initiation of lipid peroxidation. It shows hepatoprotection by two mechanisms, directly by stabilizing or delocalizing unpair electron or indirectly by stimulating antioxidant activity ${ }^{6}$.

Saponins can directly protect hepatocytes from apoptosis through a mechanism of inhibition of the production of Tumor Nuclear Factor Alpha (TNF $\alpha$ ). Alkaloids are found in abundance in almost all parts of plants and have activities in scavenging the reactive oxygen species ${ }^{7}$.Ginsenoside $\mathrm{Rb} 1, \mathrm{a}$ major saponin in ginseng, exert antinflammatory response by inhibiting proinflammatory cytokines and alleviate signalling pathway ${ }^{36}$.

Inhibitory effect of limonene on the expression of NF- $\kappa \mathrm{B}$ and its upstream TNF- $\alpha$, reduced infiltration of inflammatory cells, activation of the AMPK signaling pathway. Thus, Antioxidant, anti-inflammatory, and antiapoptotic property of limonene plays an important role ${ }^{37}$.Dlimonene present in $\mathrm{F}$. vulgare increase concentration of reduced Glutathione (GSH) which binds with NAPQI (Nacetylp-benzoquinone imine). Its mechanisms against liver fibrosis may be related with inhibiting lipid peroxidation formation in liver tissue of liver fibrosis mice and reducing the collagen formation by suppressing protein expression of TGF- $\beta_{1}, \alpha$-SMA, MMP- 9 and TIMP-138. 
Catechins are renowned for their powerful potential to scavenge various free radicals such as hydroxyl, peroxyl, superoxide, and other radicals. Antioxidant activity of catechins is mediated through different mechanisms. They are able to transfer an electron to bind a reactive radical, while they change to the more stable and less reactive phenoxyl radical. They are also able to chelate $\mathrm{Cu}^{2+}$ and $\mathrm{Fe}^{3+}$ ions, thus limiting free radicals generation. Indirectly, catechins exert an antioxidant effect by increasing the level of endogenous antioxidants such as glutathione reductase, catalase, and superoxide dismutase. Moreover, catechins are reported to have an inhibitory effect on xanthine oxidase that catalyzes the metabolism of purines into uric acid and reactive oxygen species ${ }^{39}$.

Alkaloids demonstrate hepatoprotective activity through their action in decreasing CYP2E1 mRNA and therefore CYP2E1 activity ${ }^{40}$.A study with steroidal alkaloid from S. saligna reduced liver inflammation by firstly reducing the $\mathrm{T}$ cells multiplication and amount of IL-2 which change the entire inflammation reactions and as well non-cytotoxic, secondly acts as antioxidant and act as a free radicals scavenger which is produced by the hepatocytes ${ }^{41}$.

\section{RESULT}

\section{Table 6: Result Description}

\begin{tabular}{|c|c|c|}
\hline Name of the plant & Study model & Result \\
\hline $\begin{array}{l}\text { Cichorium Intybus } \\
\text { Cynara Scolymus } 4\end{array}$ & Broiler Chicken & $\begin{array}{l}\text { Ethanolic extract of Cichorium intybus showed significant hepatoprotective } \\
\text { effect by decrease in AST and GGT concentrations at } 0.1 \% \text { alcoholic extract } \\
\text { compared to Cynara Scolymus which did not protect the liver against } \\
\text { paracetamol induced injury, both decreased the mortality rate and significant } \\
\text { gain in body weight was observed. }\end{array}$ \\
\hline Foeniculum Vulgare $^{1}$ & Rabbit & $\begin{array}{l}\text { Study result showed Foeniculum vulgare at } 500 \mathrm{mg} / \mathrm{kg} \text { as most } \\
\text { hepatoprotective. } \\
\text { Histopathological findings also supported the biochemical results. }\end{array}$ \\
\hline Cordia Sebestena L. 5 & Wistar Albino Rats & $\begin{array}{l}\text { Cordia sebestena fruit extract at dose of } 400 \mathrm{mg} / \mathrm{kg} \text { reversed liver } \\
\text { deteriorations. } \\
\text { Histopathological study revealed the regeneration of hepatocytes. }\end{array}$ \\
\hline Curcuma heyneana $^{6}$ & Wistar Albino Rats & $\begin{array}{l}\text { Administration of ethanol extract of C. Heyneana rhizome at the dose of } 25,125 \\
\text { or } 625 \mathrm{mg} / \mathrm{kg} \text { significantly inhibited the elevated liver biomarkers. Treatment } \\
\text { with doses of } 125,625 \mathrm{mg} / \mathrm{kg} \text { did not show any sign of necrosis. Ethanol extract } \\
\text { strongly scavenged DPPH. }\end{array}$ \\
\hline $\begin{array}{l}\text { Lobelia Alsinoides } \\
\text { Lam. }{ }^{2}\end{array}$ & Wistar Albino Rats & $\begin{array}{l}\text { Animals treated with the fine paste of L. Alsinoides at } 2.16 \mathrm{~g} / \mathrm{kg} \text { showed best } \\
\text { hepatoprotective activity.Histomorphologic evaluation showed } \\
\text { hepatoprotective effect with scattered mitotic figures in the parenchyma, doses } \\
\text { up to } 2500 \mathrm{mg} / \mathrm{kg} \text { are not toxic to rats, showed good anti-oxidant activity. }\end{array}$ \\
\hline $\begin{array}{l}\text { Three Varieties of } \\
\text { the Passion Fruit } \\
\text { (Passiflora Sp.) }^{7}\end{array}$ & Albino Rats & $\begin{array}{l}\text { The hepatoprotective activity and nephroprotective activity of purple passion } \\
\text { fruit peel extract at } 250 \mathrm{mg} \text { per } \mathrm{kg} \text { of body weight was best compared to red and } \\
\text { yellow peel extract. }\end{array}$ \\
\hline $\begin{array}{l}\text { Phyllanthus } \\
\text { Fraternus }^{8}\end{array}$ & Wistar rats & $\begin{array}{l}\text { P. Fraternus reduced liver biomarkers best at } 500 \mathrm{mg} / \mathrm{kg} \text { body weight , showed } \\
\text { rising total protein levels and reduction of necrosis and sinusoids was observed } \\
\text { in histopathological examination }\end{array}$ \\
\hline Pavetta Indica LINN ${ }^{9}$ & Albino Rats & $\begin{array}{l}\text { No mortality up to } 2000 \mathrm{mg} / \mathrm{kg} \text { body weight. Ethanol extract of P. Indica } \\
\text { exhibited significant hepatoprotective activity at } 100 \mathrm{mg} / \mathrm{kg} \text { and } 200 \mathrm{mg} / \mathrm{kg} \\
\text { body weight. }\end{array}$ \\
\hline Mimosa Pudica ${ }^{10}$ & Wistar Rats & $\begin{array}{l}\text { Mimosa Pudica leaves extract at } 300 \mathrm{mg} / \mathrm{kg} \text { of body weight showed } \\
\text { Hepatoprotective activity by significantly restored liver markers. }\end{array}$ \\
\hline Terminalia Coriacea $^{3}$ & Albino Rats & $\begin{array}{l}\text { METC at } 500 \mathrm{mg} / \mathrm{kg} \text {, body weight treated rats exhibited maximum depletion of } \\
\text { liver biomarkers. The histopathology study also showed the hepatic protection } \\
\text { of extracts, No lethality was observed at } 2000 \mathrm{mg} / \mathrm{kg} \text {. }\end{array}$ \\
\hline Bambusa Bambos $^{11}$ & Wistar Rats & $\begin{array}{l}\text { Methanolic shoot extract of b. Bambos at dosage } 400 \mathrm{mg} / \mathrm{kg} \text { per body weight } \\
\text { showed best hepatprotection. }\end{array}$ \\
\hline Rosa Canina ${ }^{12}$ & Albino Wistar rats & $\begin{array}{l}\text { R. Canina at doses of } 500 \text { and } 750 \mathrm{mg} / \mathrm{kg} \text { significantly reduced elevated levels of } \\
\text { ALT, AST, ALP and MDA, increased the serum levels of ALB and TP } \\
\text { histopathological studies supported the biochemical finding. }\end{array}$ \\
\hline $\begin{array}{l}\text { Garcinia } \\
\text { Pedunculata } 13\end{array}$ & Wistar albino rats & $\begin{array}{l}\text { Acute oral toxicity study did not reveal any mortality in any dose up to } 2,000 \\
\mathrm{mg} / \mathrm{kg} \text {,reduction in AST,ALT, alkaline phosphatase }\end{array}$ \\
\hline Tetrapleura & Wistar rats and & The extracts decreased the elevation in the activities of the enzymes in the liver. \\
\hline
\end{tabular}




\begin{tabular}{|l|l|l|}
\hline Tetraptera14 & mice & $\begin{array}{l}\text { They also protected against CCl4 induced lipid peroxidation at 100-500 mg/kg. } \\
\text { The extracts reduced CCl4-liver induced necrosis in dose dependent manner. }\end{array}$ \\
\hline Feijoa Sellowiana15 & Albino Wistar rats & $\begin{array}{l}\text { Dose dependently the results showed decrease in ALT, AST and GSH, necrosis in } \\
\text { the liver parenchyma also decreased. }\end{array}$ \\
\hline Piper Cubeba 16 & $\begin{array}{l}\text { Swiss Albino mice } \\
\text { and Wistar rats }\end{array}$ & $\begin{array}{l}\text { Extract had significant dose-dependent antioxidant activity in all in vitro } \\
\text { experiments, it attenuated ccl4 induced serum marker enzymes and total } \\
\text { protein and histopathology result supported the same. }\end{array}$ \\
\hline Feronia Limonia ${ }^{17}$ & Albino rats & $\begin{array}{l}\text { Treatment at } 300 \text { mg / kg of ethanolic extract of Feronia Limonia promoted } \\
\text { body weight and showed significant hepatoprotective activity }\end{array}$ \\
\hline $\begin{array}{l}\text { Solanum } \\
\text { Xanthocarpum } 18\end{array}$ & $\begin{array}{l}\text { Sprague-Dawley } \\
\text { rats and Swiss } \\
\text { albino mice }\end{array}$ & $\begin{array}{l}\text { 400 mg/kg body weight showed maximum reduction in hepatotoxicity induced } \\
\text { serum levels and reduced the lipid peroxidation in the liver tissue and restored } \\
\text { activities of defence antioxidant enzymes. } \\
\text { GSH, SOD and catalase towards normal levels and histopathology study also } \\
\text { supported the same. }\end{array}$ \\
\hline \multicolumn{2}{|l}{}
\end{tabular}

\section{DISCUSSION}

All the plants reviewed have remarkable proven hepatoprotective potential due to various miraculous phytoconstituents. The greater the content of alkaloids, flavonoids, and saponins in an extract, the higher the hepatoprotective activity possessed by the extract. Flavonoids are polyphenol compounds that have been proven for hepatocytes protection from free radical scavenging activity ${ }^{7}$. Polyphenols are a group of compounds in plants with high antioxidant potential. This antioxidant activity is mainly due to their redox potential that allows them to neutralize free radicals, singlet oxygen or decomposing peroxides ${ }^{29}$. The $n$-hexane extract lowered thiobarbituric acid reactive substance (TBARS) more than the methanol extract ${ }^{14}$, antiplasmodial effects of this plant might be correlated to his high phenolic content.Further research for active Phytoconstituents demonstrating hepatoprotective activity of C. Sebestena fruit is suggested 5 . The mechanism of the hepatoprotective action of the plant $\mathrm{L}$. Alsinoides was uncertain from the study but is assumed to be due to the capacity of the plant derivatives to prevent lipid peroxidation by its free radical scavenging activity in the liver ${ }^{2}$. Bamboo is an under-explored plant with high therapeutic potential. Bambusa vulgaris have shown great antioxidant activity and presence of saponins, alkaloids, flavonoids, phenolics tannins, phytosterols, and triterpenoids ${ }^{42}$.Investigations are required to characterize the active hepatoprotective agent and mechanism of action of Bambusa Bamboo ${ }^{11}$.Several plants are under the research and several others are still undercover to be discovered for their possible hepatoprotective activity, this is the need of an hour as liver diseases are a growing threat.

\section{REFERENCES}

1. Nazir T, Shakir L, Zaka-ur-Rahman, Najam K, Choudhary A, Saeed $\mathrm{N}$, et al. Hepatoprotective Activity of Foeniculum vulgare Against Paracetamol Induced Hepatotoxicity in Rabbit. Journal of Applied Pharmacy[Internet]. 2020 [cited 2021 Nov 7]; 12(1). https://doi.org/10.35248/2376-0354.20.12.270 Available from:https://www.longdom.org/open-

access/hepatoprotective-activity-of-emfoeniculum-vulgareemagainst-paracetamol-induced-hepatotoxicity-in-rabbit47551.html

2. Binitha RRV, Shajahan MA, Muhamed J, Anilkumar TV, Premlal S, Indulekha VC.Hepatoprotective effect of Lobelia alsinoides Lam. in Wistar rats. Journal of Ayurveda and Integrative Medicine. 2020 Oct; $11(4): 515-21$.

https://pubmed.ncbi.nlm.nih.gov/31277907/

https://doi.org/10.1016/j.jaim.2019.04.004
3. Patel J, Reddy AV, Kumar GS, Satyasai D, Bajari B, Nagarjuna V. Hepatoprotective activity of methanolic extract of Terminalia coriacea leaves. Research Journal of Pharmacy and Technology. 2017; 10(5):1313. https://doi.org/10.5958/0974-

360X.2017.00232.3

https://www.researchgate.net/publication/318501680_Hepato protective_activity_of_methanolic_extract_of_Terminalia_coriace a_leaves

4. Andalib F, Moosavian H, Khazraeinia P, Mohajerani S, Pourakbari S. Comparison of Hepatoprotective Activity of Cichorium Intybus and Cynara Scolymus Extracts Against Paracetamol Induced Hepatotoxicity in Broiler Chicken. Egyptian Journal of Veterinary Sciences. 2021 Aug 1; 52(2):251-6. https://doi.org/10.21608/ejvs.2021.48017.1200 https://journals.ekb.eg/article_164041.html

5. Chaudhary S, Gupta RK, Gupta MK, Verma HC, Kumar H, Swain SR, et al. Hepatoprotective response of Cordia sebestena L. fruit against simvastatin induced hepatotoxicity. Journal of Pharmacy \& Pharmacognosy Research2020; 8 (4):327-335 http://jppres.com/jppres

6. Marianne M, Harahap U, Hasibuan PAZ, Thampati CM, Harefa HS. Hepatoprotective activity of the ethanol extract of Curcuma heyneana rhizome on isoniazid and rifampin-induced liver injury rats. Journal of Herbmed Pharmacology.2020 Jul 1; 9(4):333-8. https://doi.org/10.34172/jhp.2020.42 http://herbmedpharmacol.com/Article/jhp-13392

7. Nerdy N, Ritarwan K. Hepatoprotective Activity and Nephroprotective Activity of Peel Extract from Three Varieties of the Passion Fruit (Passiflora Sp.) in the Albino Rat. Open Access Maced J Med Sci. 2019 Feb 27; 7(4):536-42. https://doi.org/10.3889/oamjms.2019.153 https://www.ncbi.nlm.nih.gov/pmc/articles/PMC6420947/

8. Alasyam N, Pokala N, John P. Evaluation of hepatoprotective activity of aqueous extract of Phyllanthus fraternus in Wistar rats. National Journal of Physiology Pharmacy and Pharmacology. 2019; 9(3):1. https://doi.org/10.5455/njppp.2019.9.1237012012019 http://www.njppp.com/index.php?mno=22056

9. Singh M P, Valte V,Raleng I,RK SL.Hepatoprotective activity of ethanol extract of Pavetta Indica Linn leaves.Indian Journal of Pharmacy and Pharmacology.2020 Dec 28; 5(1):37-9. https://doi.org/10.18231/2393-9087.2018.0009 http://oaji.net/articles/2017/1495-1525332796.pdf

10. Rajendiran D,Raghavan S,Kandaswamy S,and Gunasekaran K. Hepatoprotective activity of ethanol extract of Mimosa pudica leaves in type 2 diabetic rats. The Pharma Innovation Journal 2018; 7(12):223-226 https://www.thepharmajournal.com/archives/?year=2018\&vol $=7$ \&issue $=12$ \&ArticleId $=2824$

11. Patil A.A.S.S,Hoskeri H.J, P Rajeev, Kulkarni B,Kamble G.R,Hiremath G.B, Kalebar V, Hiremath S.V.Hepatoprotective 
activity of methanolic shoot extract of Bambusa bambos against carbon tetrachloride induce acute liver toxicity in Wistar rats. J App Biol Biotech. 2018; 37-40.

https://doi.org/10.7324/JABB.2018.60407

https://jabonline.in/admin/php/uploads/284_pdf.pdf

12. Sadeghi H, Hosseinzadeh S, Touri MA, Barmak MJ. Hepatoprotective effect of Rosa canina fruit extract against carbon tetrachloride induced hepatotoxicity in rat.Avicenna J Phyto Med.2016; 6(2):8 https://www.ncbi.nlm.nih.gov/pmc/articles/PMC4877970/

13. Mundugaru R, Chakkravarthy M, Basavaiah R. Hepatoprotective activity of fruit extract garcinia pedunculata. Bangladesh J Pharmacol. 2014 Oct 1; 9(4):483-7. https://doi.org/10.3329/bjp.v9i4.19910 https://www.researchgate.net/publication/282162075_Hepato protective_activity_of_fruit_extract_of_Garcinia_pedunculata

14. Okoli J TN,Agbo MO, and Ukekwe FI.Antioxidant and Hepatoprotective Activity of Fruit Extracts of Tetrapleura tetraptera (Schum \& Thonn) Taubert. Jordan Journal of Biological Sciences. 2014 December; 7(4):1995-6673 https://doi.org/10.12816/0008247 https://jjbs.hu.edu.jo/files/v7n4/Paper\%20Number\%203m.pd

15. Karami M, Saeidnia S, Nosrati A. Study of the Hepatoprotective Activity of Methanolic Extract of Feijoa sellowiana Fruits Against MDMA using the Isolated Rat Liver Perfusion System.Iranian Journal of Pharmaceutical Research. 2013; 12 (1):85-91

https://www.ncbi.nlm.nih.gov/pmc/articles/PMC3813203/

16. Pachpute AP,Deshmukh TA. Antioxidant and hepatoprotective activity of an ethanol extract of piper cubeba fruits.International Journal Of Research And Development In Pharmacy And Life Sciences. 2013 February - March; 2(2):321-329 http://citeseerx.ist.psu.edu/viewdoc/download?doi=10.1.1.392 $.2666 \&$ rep $=$ rep $1 \&$ type $=p d f$

17. Dar AI, Saxena RC, Bansal SK. Assessment of hepatoprotective activity of fruit pulp of Feronia limonia (Linn.) against paracetamol induced hepatotoxicity in albino rats. Journal of Natural Products.2012; 2 (2):226-233 https://www.scholarsresearchlibrary.com/abstract/assessmen t-of-hepatoprotective-activity-of-fruit-pulp-of-feronialimoniarnlinn-against-paracetamol-induced-hepatotoxicit5201.htm

18. Gupta RK, Hussain T, Panigrahi G, Das A, Singh GN, Sweety K, et al. Hepatoprotective effect of Solanum xanthocarpum fruit extract against $\mathrm{CCl} 4$ induced acute liver toxicity in experimental animals. Asian Pacific Journal of Tropical Medicine. 2011 Dec; 4(12):964-8. https://doi.org/10.1016/S1995-7645(11)60227-7 https://pubmed.ncbi.nlm.nih.gov/22118032/

19. Pandit A,Sachdeva T and Bafna P. Drug-Induced Hepatotoxicity: A Review. J App Pharm Sci [Internet]. 2012 May 28 [cited 2021 Nov 8]; Available from: http://www.japsonline.com/vol-2issue-5/233-243.pdf

20. Fisher K, Vuppalanchi R, Saxena R. Drug-Induced Liver Injury. Arch Pathol Lab Med. 2015; 139:12.

https://doi.org/10.5858/arpa.2014-0214-RA

https://pubmed.ncbi.nlm.nih.gov/26125428/

21. David S, Hamilton JP. Drug-induced Liver Injury. NIH Public Access.2010 January 1; 6:73-80 https://www.ncbi.nlm.nih.gov/pmc/articles/PMC3160634/

22. Rotundo L, Pyrsopoulos N. Liver injury induced by paracetamol and challenges associated with intentional and unintentional use. WJH. 2020 Apr 27; 12(4):125-36. https://doi.org/10.4254/wjh.v12.i4.125 https://pubmed.ncbi.nlm.nih.gov/32685105/

23. Björnsson ES. Hepatotoxicity of statins and other lipid-lowering agents. Liver Int.2017 Feb; 37(2):173-8. https://doi.org/10.1111/liv.13308 https://pubmed.ncbi.nlm.nih.gov/27860156/
24. Karahalil B, Hare E, Koç G, Uslu İ, Şentürk K, Özkan Y. Hepatotoxicity associated with statins. Archives of Industrial Hygiene and Toxicology. 2017 Dec 20; 68(4):254-60. https://doi.org/10.1515/aiht-2017-68-2994 https://pubmed.ncbi.nlm.nih.gov/29337684/

25. Singh R, Chahal KK. Cichorium intybus L: A review on phytochemistry and pharmacology. International Journal of Chemical Studies, ; 6(3):1272-1280 https://www.researchgate.net/profile/Ravinder-Singh56/publication/332013279_Cichorium_intybus_L_A_review_on phytochemistry_and_pharmacology/links/60f01b420859317db de35df8/Cichorium-intybus-L-A-review-on-phytochemistryand-pharmacology.pdf

26. Anju, Javed G, Javaid R, Ahmed F. Kasni (Cichorium intybus): A Unani Hepatoprotective Drug. J Drug Delivery Ther. 2020 Jul 15; 10(4):238-41. https://doi.org/10.22270/jddt.v10i4.4162 http://jddtonline.info/index.php/jddt/article/view/4162

27. Richa U and Nath T.K. Phyllanthus fraternus a potent natural antioxidant as pharmaceutical supplement. Research Journal of Biotechnology. 2018 September; 13(9)

https://www.researchgate.net/publication/327513712_Phyllanthu s_fraternus_a_potent_natural_antioxidant_as_pharmaceutical_su pplement

28. Seena H, Kannappan N, Manojkumar P. Evaluation of Phytochemical,anti-oxidant and hepatoprotective activities of methanolic extract of Pavetta Indica. Asian Journal of Research in Chemistry and Pharmaceutical Sciences. 2019; 7(2):379-387.

29. Saague PWK, Moukette Moukette B, Njimou JR, Biapa PCN, Nzufo Tankeu F, Moor VJA, et al. Phenolic Compounds from WaterEthanol Extracts of Tetrapleura tetraptera Produced in Cameroon, as Potential Protectors against In Vivo CC 14 Induced Liver Injuries. The Scientific World Journal. 2019 Mar 3; 2019:1-10. https://doi.org/10.1155/2019/5236851 https://www.hindawi.com/journals/tswj/2019/5236851/

30. AlSaid M, Mothana R, Raish M, Al-Sohaibani M, Al-Yahya M, Ahmad A, et al. Evaluation of the Effectiveness of Piper cubeba Extract in the Amelioration of CCl 4 -Induced Liver Injuries and Oxidative Damage in the Rodent Model. BioMed Research International. 2015; 2015:1-11. https://doi.org/10.1155/2015/359358 https://www.hindawi.com/journals/bmri/2015/359358/

31. Saha P, Talukdar AD, Nath R, Sarker SD, Nahar L, Sahu J, et al. Role of Natural Phenolics in Hepatoprotection: A Mechanistic Review and Analysis of Regulatory Network of Associated Genes. Front Pharmacol. 2019 May 24; 10:509. https://doi.org/10.3389/fphar.2019.00509 https://www.frontiersin.org/articles/10.3389/fphar.2019.005 09/full

32. Wan LJjiang JG.Protective effects of plant-derived flavonoids on hepatic injury.Joural of functional food.2018 May; 44:17564646. https://doi.org/10.1016/j.jff.2018.03.015 https://www.sciencedirect.com/science/article/abs/pii/S1756 464618301014

33. Khan MSA,Ahmed N,Arifuddin MM,Zakaria ZA,Sanea MMA,Khundmiri SUK,Ahmed I,Ahmed S,Mok PL.Antinociceptive mechanisms of flavonoids-rich methanolic extract from Terminalia coriacea (Roxb.) Wight \& Arn. Leaves.Food and Chemical Toxicology. 2018; 115:0278-6915 https://doi.org/10.1016/j.fct.2018.03.021 https://www.sciencedirect.com/science/article/abs/pii/S0278 691518301704

34. He Y,Xia Z,Yu D,Wang J,Jin L,Huang D,Ye X,Li X,Zhang B.Hepatoprotective effects and structure-activity relationship of five flavonoids against lipopolysaccharide/d-galactosamine induced acute liver failure in mice.International Immunopharmacology. 2019; 68:1567-5769. https://doi.org/10.1016/j.intimp.2018.12.059 https://www.sciencedirect.com/science/article/pii/S1567576 918309251

35. Mohamadi-Zarch S-M, Baluchnejadmojarad T, Nourabadi D, Ramazi S, Nazari-Serenjeh M, Roghani M. Esculetin Alleviates 
Acute Liver Failure following Lipopolysaccharide/D-

Galactosamine in Male C57BL/6 Mice. Iranian Journal of Medical Sciences [Internet]. 2021 Mar [cited 2021 Nov 8]; (Online First). Available from:

https://doi.org/10.30476/ijms.2020.84909.1474

36. Ren S,Leng J,Xu X,Jiang S,Wang YP,Yan XT,Liu Z,Chen C,Wang Z and Li W.Ginsenoside Rb1, A Major Saponin from Panax ginseng, Exerts Protective Effects Against Acetaminophen-Induced Hepatotoxicity in Mice. The American Journal of Chinese Medicine. 2019; 47(8)

https://doi.org/10.1142/S0192415X19500927

https://www.worldscientific.com/doi/epdf/10.1142/S019241 $5 \times 19500927$

37. Amini R, Asle-Rousta M, Aghazadeh S. Hepatoprotective effect of limonene against chronic immobilization induced liver damage in rats. Naunyn-Schmiedeberg's Arch Pharmacol. 2020 Nov; 393(11):2053-9. https://doi.org/10.1007/s00210-020-019150 https://pubmed.ncbi.nlm.nih.gov/32514601/

38. Zhang C, Tian X, Zhang K, Li G-Y, Wang H-Y, Wang J-H. Protective effects of Foeniculum vulgare root bark extract against carbon tetrachloride-induced hepatic fibrosis in mice. WJG. 2017; 23(31):5722 https://doi.org/10.3748/wjg.v23.i31.5722 https://www.ncbi.nlm.nih.gov/pmc/articles/PMC5569286/

39. Sobeh M, Mahmoud MF, Hasan RA, Abdelfattah MAO, Sabry OM, Ghareeb MA, et al. Tannin-rich extracts from Lannea stuhlmannii and Lannea humilis (Anacardiaceae) exhibit hepatoprotective activities in vivo via enhancement of the antiapoptotic protein Bcl-2. Sci Rep. 2018 Dec; 8(1):9343. https://doi.org/10.1038/s41598-018-27452-8 https://europepmc.org/article/pmc/pmc6008440

40. Lin J, Zhao J, Li T, Zhou J, Hu J, Hong Z. Hepatoprotection in a Rat Model of Acute Liver Damage Through Inhibition of CY2E1 Activity by Total Alkaloids Extracted From Rubus alceifolius Poir. Int J Toxicol. 2011 Mar; 30(2):237-43. https://doi.org/10.1177/1091581810390711 https://journals.sagepub.com/doi/full/10.1177/10915818103 90711

41. Jan NU, Ahmad B, Ali S, Adhikari A, Ali A, Jahan A, et al. Steroidal Alkaloids as an Emerging Therapeutic Alternative for Investigation of Their Immunosuppressive and Hepatoprotective Potential. Front Pharmacol [Internet]. 2017 Mar 21 [cited 2021 Nov 8]; 8. Available from: http://journal.frontiersin.org/article/10.3389/fphar.2017.0011 4/full https://doi.org/10.3389/fphar.2017.00114

42. Fitri A, Asra R, Rivai H. Overview of the traditional, phytochemical, and pharmacological uses of gold bamboo (Bambusa Vulgaris). World Journal of Pharmacy and Pharmaceutical Sciences. 9(8):21. https://www.researchgate.net/publication/343362147_OVERV IEW_OF_THE_TRADITIONAL_PHYTOCHEMICAL_AND_PHARMA COLOGICAL_USES_OF_GOLD_BAMBOO_BAMBUSA_VULGARIS 